DOI 10.31558/2307-2318.2019.3.3

УДК 338: 657.1

Гевлич І.Г., к.т.н., доцент, доцент кафедри бізнес-статистики i економічної кібернетики, Донецький національний університет імені Василя Стуса

Бабій А.В., магістрант, Донецький національний університет імені Василя Стуса

\title{
ЕКОНОМІЧНИЙ ЗМІСТ ЗАБОРГОВАНОСТІ ПЕРЕД ПОСТАЧАЛЬНИКАМИ ТА ПІДРЯДНИКАМИ В РАМКАХ ПРИЙНЯТТЯ УПРАВЛІНСЬКИХ РІШЕНЬ
}

Кредиторська заборгованість, зокрема, заборгованість перед постачальниками та підрядниками є вагомою складовою позикового капіталу як джерела фінансування будь-якого підприємства. Ефективне управління нею передбачає оптимізацію розміру і структури, що неможливо без усвідомлення менеджерами-практиками сутності дефініції. 3 урахуванням впливу кредиторської заборгованості на фінансові показники суб'єкта господарювання та його діловий імідж у цілому, дослідження ії сутності $\epsilon$ актуальним. Дотепер невирішеним залишається питання єдності трактування кредиторської заборгованості у наукових дискусіях та облікових регламентах, що негативно позначається на ефективності менеджменту на мікрорівні. Метою статті $€$ дослідження економічного змісту кредиторської заборгованості у роботах вітчизняних вчених і нормативних регламентах з точки зору визначення ії впливу на ефективність управління. В роботі наданий критичний аналіз праць вітчизняних науковців щодо досліджень кредиторської заборгованості та здійснено порівняльний аналіз національних і міжнародних регламентів щодо їі обліку. За результатами дослідження ідентифікована проблема відсутності єдиного трактування поняття кредиторської заборгованості у вітчизняних облікових регламентах як фактор, що утруднює ефективне управління розрахунками із постачальниками та підрядниками. Також виявлені такі проблемні моменти управління кредиторською заборгованістю: відсутність окремого нормативно-правового акту регулювання обліку кредиторської заборгованості в Україні, розбіжності у трактуванні термінів, визнанні, класифікації, оцінці заборгованості у вітчизняних та міжнародних облікових стандартах. Для вирішення ідентифікованих проблем запропоновано застосування міжнародних стандартів в якості обов'язкових для всіх суб'єктів господарювання в Україні. Напрямом подальших досліджень визначено пошук шляхів вдосконалення процесу управління кредиторською заборгованістю.

Ключові слова: кредиторська заборгованість, зобов'язання, управлінські рішення, економічний зміст, постачальники та підрядники.

Гевлич И.Г., Бабий А.В.

ЭКОНОМИЧЕСКОЕ СОДЕРЖАНИЕ ЗАДОЛЖЕННОСТИ ПЕРЕД ПОСТАВЩИКАМИ И ПОДРЯДЧИКАМИ В РАМКАХ ПРИНЯТИЯ УПРАВЛЕНЧЕСКИХ РЕШЕНИЙ

Кредиторская задолженность, в частности, задолженность перед поставщиками и подрядчиками является весомой составляющей заемного капитала как источника финансирования любого предприятия. Эффективное управление нею предусматривает оптимизацию размера и структуры, что невозможно без осознания менеджерамипрактиками сущности дефиниции. С учетом влияния кредиторской задолженности на финансовые показатели предприятия и его деловой имидж в целом, исследование ее сущности является актуальным. До сих пор нерешенным остается вопрос единства 
трактовки кредиторской задолженности в научных дискуссиях и учетных регламентах, что отрицательно сказывается на эффективности менеджмента на микроуровне. Целью статьи является исследование экономического содержания кредиторской задолженности в работах отечественных ученых и нормативных регламентах с точки зрения определения ее влияния на эффективность управления. В работе предоставлен критический анализ работ отечественных ученых относительно исследований кредиторской задолженности и осуществлен сравнительный анализ национальных и международных регламентов по ее учету. По результатам исследования идентифицирована проблема отсутствия единой трактовки понятия кредиторской задолженности в отечественных учетных регламентах как фактор, затрудняющий эффективное управление расчетами с поставщиками и подрядчиками. Также выявлены следующие проблемные моменты управления кредиторской задолженностью: отсутствие отдельного нормативно-правового акта регулирования учета кредиторской задолженности в Украине, различия в трактовке терминов, признании, классификации, оценке задолженности в отечественных и международных учетных стандартах. Для решения идентифицированных проблем предложено применение международных стандартов в качестве обязательных для всех субъектов хозяйствования в Украине. Направлением дальнейших исследований определен поиск путей совершенствования процесса управления кредиторской задолженностью.

Ключевые слова: кредиторская задолженность, обязательства, управленческие решения, экономическое содержание, поставщики и подрядчики.

\section{Hevlych I.G., Babii A.V. \\ ECONOMIC CONTENT OF DEBT TO SUPPLIERS AND CONTRACTORS IN THE FRAMEWORK OF MANAGEMENT DECISION-MAKING}

Accounts payable, in particular, payables to suppliers and contractors are a significant component of debt capital as a source of financing for any business. Effective management of it involves optimization of size and structure, which is impossible without awareness of the definition of the essence by managers. Given the impact of payables on the financial performance of the entity and its business image as a whole, the study of its nature is relevant. The question of the unity of the treatment of accounts payable in scientific discussions and accounting regulations remains unanswered so far, which negatively affects the effectiveness of micro-level management. The purpose of the article is to study the economic content of accounts payable in the work of domestic scientists and regulations in terms of determining its impact on management efficiency. The paper provides a critical analysis of the works of domestic scientists in the field of accounts payable research and provides a comparative analysis of national and international regulations on its accounting. According to the results of the research, the problem of lack of uniform interpretation of the concept of accounts payable in domestic accounting regulations was identified as a factor that impedes effective management of settlements with suppliers and contractors. Also identified are the following problematic aspects of debt management: the lack of a separate legal act regulating the accounting of accounts payable in Ukraine, differences in the interpretation of terms, recognition, classification, assessment of debt in domestic and international accounting standards. To address the identified issues, it is proposed to apply international standards as binding on all entities in Ukraine. The direction of further research is the search for ways to improve the process of debt management.

Keywords: accounts payable, liabilities, management decisions, economic content, suppliers and contractors. 
Постановка проблеми. Суб'єкти господарювання для забезпечення безперервності діяльності використовують різноманітні джерела фінансування, вагому частину яких складає позиковий капітал, зокрема кредиторська заборгованість, а саме, заборгованість перед постачальниками та підрядниками. Вона виступає джерелом більш дешевого порівняно із банківським кредитуванням короткострокового фінансування підприємств, що мотивує значне залучення цієї заборгованості будь-яким підприємством. 3 іншого боку, велика питома вага кредиторської заборгованості в структурі пасивів підприємства погіршує показники його ліквідності i платоспроможності, а несвоєчасне погашення заборгованості спричиняє сплату штрафних санкцій та псує імідж суб'єкта господарювання.

Аналіз останніх досліджень і публікацій. Дослідженням теоретичних засад обліку кредиторської заборгованості за розрахунками 3 постачальниками i підрядниками займалися такі вітчизняні вчені, як В.В. Дублей, М.М. Гуменюк, О.Б. Чорненька, М.П. Хохлов, О.С. Корнієнко, О.С. Майборода, І.П. Косарєва, І.О. Корабейнікова, О.Ф. Томчук та інші [1-6]. Незважаючи на те, що кількість наукових дослідження 3 даної тематики $\epsilon$ значною, на сьогодні невирішеним залишається питання єдності трактування поняття кредиторської заборгованості, що негативно позначається на прийнятті ефективних управлінських рішень.

Мета статті полягає у вивченні економічного змісту кредиторської заборгованості у працях вітчизняних вчених і нормативних регламентах 3 точки зору дослідження іiї впливу на ефективність управління.

Виклад основного матеріалу. Модель управління кредиторською заборгованістю містить такі складові елементи, як:

1) статичний та динамічний аналіз формування та погашення кредиторської заборгованості суб'єкта господарювання та іï впливу на величину його грошових потоків;

2) обгрунтування доцільності отримання відстрочки оплати рахунків постачальників, а також оптимального терміну такої відстрочки;

3) попередження формування простроченої кредиторської заборгованості та забезпечення пролонгації кредиторської заборгованості тощо [1].

В цілому ефективне управління кредиторською заборгованістю передбачає оптимізацію іï розміру і структури, що неможливо без усвідомлення менеджерами сутності дефініцій, які використовуються в обліку розрахунків із постачальниками та підрядниками.

Більшість науковців по-різному визначають поняття самої кредиторської заборгованості. Так, А. Б. Борисов визначає кредиторську заборгованість як грошові кошти, що тимчасово підпорядковані підприємству та підлягають поверненню юридичній або фізичній особі, у яких вони позичені або невиплачені. На думку Ф.Ф. Бутинця та Л.Л. Горецької кредиторська заборгованість - це форма розрахунку за товари та послуги, придбані під час регулярно повторюваних операцій підприємства та використовувані для переробки (як сировина) або для подальшого перепродажу. С.Ф.Голов та В.М. Костюченко зазначають, що це суми, які нараховуються постачальникам за купівлю у них товарів або послуг в кредит. Г.О. Партин та А.Г. Загородній наголошують, що кредиторська заборгованість - це заборгованість підприємства іншим юридичним і фізичним особам, що виникла в результаті здійснених раніше дій (подій), оцінена в гривнях, щодо якої в підприємства існують зобов'язання іiі погашення в певний строк. О. В. Лишиленко визначає кредиторську заборгованість як заборгованість підприємства перед іншими суб'єктами 
підприємницької діяльності (постачальниками, підрядниками, покупцями) за поставлені від них засоби і предмети праці, виконані роботи або отриману передоплату. Н.М. Ткаченко стверджує, що це тимчасово залучені суб'єктом у власне користування грошові кошти, які підлягають поверненню юридичній або фізичній особі. О.В. Олійник, М.М. Шигун, С.М. Шулепова зазначають що зобов'язання - це борги (заборгованість) підприємства, які виникають внаслідок придбання товарів і послуг у кредит, або кредити, які підприємство отримує для свого фінансування. Схоже визначення надають В.Ф. Палій та В.В. Палій, які під зобов'язаннями розуміють позиковий капітал, що необхідно повернути кредиторам у встановлені терміни, як правило, з відсотками, обумовленими договорами за його використання. В.В. Дублей та М.М. Гуменюк досліджуючи різні підходи до трактування даних понять, дійшли висновку, що зобов'язання - це правовідносини між сторонами, що мають документальне підтвердження та за яких одна сторона зобов'язується вчинити певну дію або утриматися від такої на користь іншого суб'єкта, а інший суб'єкт має право вимагати від боржника виконання його обов'язку [2]. О.Б. Чорненька пропонує кредиторську заборгованість визначати як результат правовідносин суб'єкта господарювання, який є наслідком вчинення певної дії одного суб'єкта до іншого суб'єкта господарювання, фізичної особи, держави, позабюджетного фонду щодо передачі товарно-матеріальних цінностей, грошових коштів чи інших активів, надання послуг, виконання робіт, або дії законодавчо-нормативних документів (виникнення заборгованості 3 податків чи інших обов'язкових платежів перед бюджетом та позабюджетними цільовими фондами) та надає кредитору право вимоги [3]. М.П. Хохлов та О.С. Корнієнко вважають що кредиторська заборгованість - це позичені підприємством в інших юридичних і фізичних осіб грошові кошти, оцінені в гривнях, щодо яких у підприємства існують зобов'язання погашення у певний строк [4]. О.Є. Майборода, І.П. Косарєва, І.О. Корабейнікова надали таке визначення кредиторської заборгованості: це правові відносини між сторонами, які мають документальне підтвердження щодо тимчасового залучення підприємством у власне користування грошових коштів, які не належать підприємству, або це різновид комерційного кредиту, форма розрахунку за товари і послуги, які придбаються [5]. Із тим, що кредиторська заборгованість $є$ різновидом комерційного кредиту, погоджується і О.Ф. Томчук, додаючи, що така заборгованість виступає важливим фактором стабілізації фінансового стану підприємства [6].

Дослідження вітчизняної нормативної бази дало змогу виявити, що в Україні відсутній окремий регламент для регулювання суто кредиторської заборгованості, але використовується близьке за змістом поняття зобов'язань. Так, у Законі України «Про бухгалтерський облік та фінансову звітність в Україні» [7] та НП(С)БО 1 «Загальні вимоги до фінансової звітності» [8] зобов'язання розглядається як заборгованість підприємства, яка виникла внаслідок минулих подій і погашення якої в майбутньому, як очікується, призведе до зменшення ресурсів підприємства, що втілюють у собі економічні вигоди. Поняття зобов'язань розглядається також і в Цивільному кодексі України [9]: у ст. 509 зазначено що зобов'язанням є правовідношення, в якому одна сторона (боржник) зобов'язана вчинити на користь другої сторони (кредитора) певну дію (передати майно, виконати роботу, надати послугу, сплатити гроші тощо) або утриматися від певної дії, а кредитор має право вимагати від боржника виконання його обов'язку.

Таким чином, можна бачити, що дана дефініція має різне тлумачення з правової та облікової точок зору: якщо в цивільному праві наголос робиться на суб'єктах 
розрахунків (боржник i кредитор), то в облікових регламентах цей пріоритет утрачається. Визначення понять «кредиторська заборгованість» та «зобов'язання»у роботах вітчизняних дослідників та нормативних актах узагальнено в табл. 1.

Таблиця 1

Визначення дефініцій заборгованості у наукових дослідженнях та вітчизняних регламентах

\begin{tabular}{|c|c|c|}
\hline Термін & Визначення & Джерело \\
\hline 1 & 2 & 3 \\
\hline $\begin{array}{l}\text { Кредиторська } \\
\text { заборгованість }\end{array}$ & $\begin{array}{l}\text { грошові кошти, які тимчасово підпорядковані підприємству, фірмі, } \\
\text { які підлягають поверненню юридичній або фізичній особі, у яких } \\
\text { вони позичені і яким вони невиплачені }\end{array}$ & А.Б. Борисов \\
\hline $\begin{array}{l}\text { Кредиторська } \\
\text { заборгованість }\end{array}$ & $\begin{array}{l}\text { форма розрахунку за товари та послуги, придбані під час регулярно } \\
\text { повторюваних операцій підприємства та використовувані для } \\
\text { переробки (як сировина) або для подальшого перепродажу }\end{array}$ & $\begin{array}{l}\text { Ф.Ф.Бутинець, } \\
\text { Л.Л. Горецька }\end{array}$ \\
\hline $\begin{array}{l}\text { Кредиторська } \\
\text { заборгованість }\end{array}$ & $\begin{array}{l}\text { суми, які нараховуються постачальникам за купівлю у них товарів } \\
\text { або послуг в кредит }\end{array}$ & $\begin{array}{l}\text { С.Ф. Голов,В.М. } \\
\text { Костюченко }\end{array}$ \\
\hline $\begin{array}{l}\text { Кредиторська } \\
\text { заборгованість }\end{array}$ & $\begin{array}{l}\text { заборгованість підприємства іншим юридичним і фізичним особам, } \\
\text { що виникла в результаті здійснених раніше дій (подій), оцінена в } \\
\text { гривнях і щодо якої в підприємства існують зобов'язання ії } \\
\text { погашення в певний строк }\end{array}$ & $\begin{array}{l}\text { Г.О. Партин, } \\
\text { А.Г. Загородній }\end{array}$ \\
\hline $\begin{array}{l}\text { Кредиторська } \\
\text { заборгованість }\end{array}$ & $\begin{array}{l}\text { заборгованість підприємства перед іншими суб'єктами } \\
\text { підприємницької діяльності } \quad \text { (постачальниками, підрядниками, } \\
\text { покупцями) за поставлені від них засоби і предмети праці, виконані } \\
\text { роботи або отриману передоплату }\end{array}$ & О.В. Лишиленко \\
\hline $\begin{array}{l}\text { Кредиторська } \\
\text { заборгованість }\end{array}$ & $\begin{array}{l}\text { тимчасово залучені суб'єктом у власне користування грошові } \\
\text { кошти, які підлягають поверненню юридичній або фізичній особі }\end{array}$ & Н.М. Ткаченко \\
\hline $\begin{array}{l}\text { Кредиторська } \\
\text { заборгованість }\end{array}$ & $\begin{array}{l}\text { результат правовідносин суб'єкта господарювання, який є } \\
\text { наслідком вчинення певної дії одного суб’єкта до іншого суб’єкта } \\
\text { господарювання, фізичної особи, держави, позабюджетного фонду } \\
\text { щодо передачі ТМЦ, грошових коштів чи інших активів, надання } \\
\text { послуг, виконання робіт, або дії законодавчо-нормативних } \\
\text { документів (виникнення заборгованості } 3 \text { податків чи інших } \\
\text { обов'язкових платежів перед бюджетом та позабюджетними } \\
\text { цільовими фондами) та надає кредитору право вимоги }\end{array}$ & О.Б. Чорненька \\
\hline $\begin{array}{l}\text { Кредиторська } \\
\text { заборгованість }\end{array}$ & $\begin{array}{l}\text { позичені підприємством в інших юридичних і фізичних осіб } \\
\text { грошові кошти, оцінені в гривнях, щодо яких у підприємства } \\
\text { існують зобов'язання погашення у певний строк }\end{array}$ & $\begin{array}{l}\text { М.П. Хохлов, } \\
\text { О.С. Корнієнко }\end{array}$ \\
\hline $\begin{array}{l}\text { Кредиторська } \\
\text { заборгованість }\end{array}$ & $\begin{array}{l}\text { правові відносини між сторонами, які мають документальне } \\
\text { підтвердження щодо тимчасового залучення підприємством у } \\
\text { власне користування грошових коштів, які не належать } \\
\text { підприємству, або це різновид комерційного кредиту, форма } \\
\text { розрахунку за товари і послуги, які придбаються }\end{array}$ & $\begin{array}{l}\text { О.Є. Майборода, } \\
\text { І.П. Косарєва, } \\
\text { І.О. Корабейнікова }\end{array}$ \\
\hline $\begin{array}{l}\text { Кредиторська } \\
\text { заборгованість }\end{array}$ & $\begin{array}{l}\text { різновид комерційного кредиту, який виступає важливим фактором } \\
\text { стабілізації фінансового стану підприємства }\end{array}$ & О.Ф. Томчук \\
\hline Зобов’язання & $\begin{array}{l}\text { борги (заборгованість) підприємства, які виникають внаслідок } \\
\text { придбання товарів і послуг у кредит, або кредити, які підприємство } \\
\text { отримує для свого фінансування }\end{array}$ & $\begin{array}{l}\text { О.В. Олійник, } \\
\text { М.М. Шигун, } \\
\text { С.М. Шулепова }\end{array}$ \\
\hline Зобов’язання & $\begin{array}{l}\text { позиковий капітал, який необхідно повернути кредиторам у } \\
\text { встановлені терміни, як правило, } 3 \text { відсотками, які обумовлені } \\
\text { договорами за його використання }\end{array}$ & $\begin{array}{l}\text { В.Ф. Палій, } \\
\text { В.В. Палій }\end{array}$ \\
\hline Зобов’язання & $\begin{array}{l}\text { правовідносини між сторонами, які мають документальне } \\
\text { підтвердження та за яких одна сторона зобов'язується вчинити } \\
\text { певну дію або утриматися від такої на користь іншого суб'єкта, а } \\
\text { інший суб'єкт має право вимагати від боржника виконання його } \\
\text { обов'язку. }\end{array}$ & $\begin{array}{l}\text { В.В. Дублей, } \\
\text { М.М. Гуменюк }\end{array}$ \\
\hline
\end{tabular}


Продовження табл. 1

\begin{tabular}{|c|c|c|}
\hline 1 & 2 & 3 \\
\hline Зобов'язання & $\begin{array}{l}\text { правовідносини між сторонами, які мають документальне } \\
\text { підтвердження та за яких одна сторона зобов'язується вчинити } \\
\text { певну дію або утриматися від такої на користь іншого суб'єкта, а } \\
\text { інший суб'єкт має право вимагати від боржника виконання його } \\
\text { обов'язку. }\end{array}$ & $\begin{array}{l}\text { В.В. Дублей, } \\
\text { М.М. Гуменюк }\end{array}$ \\
\hline Зобов'язання & $\begin{array}{l}\text { заборгованість підприємства, яка виникла внаслідок минулих подій } \\
\text { i погашення якої в майбутньому, як очікується, призведе до } \\
\text { зменшення ресурсів підприємства, що втілюють у собі економічні } \\
\text { вигоди }\end{array}$ & $\begin{array}{l}\text { ЗУ «Про бух. облік та } \\
\text { фін. звітність в } \\
\text { Україні», НП(С)БО } 1 \\
\text { «Загальні вимоги до } \\
\text { фін. звітності» }\end{array}$ \\
\hline Зобов'язання & $\begin{array}{l}\text { правовідношення, в якому одна сторона (боржник) зобов'язана } \\
\text { вчинити на користь другої сторони (кредитора) певну дію } \\
\text { (передати майно, виконати роботу, надати послугу, сплатити гроші } \\
\text { тощо) або угриматися від певної дії, а кредитор має право вимагати } \\
\text { від боржника виконання його обов’язку }\end{array}$ & $\begin{array}{l}\text { Цивільний кодекс } \\
\text { України }\end{array}$ \\
\hline
\end{tabular}

Методика ведення бухгалтерського обліку зобов'язань в Україні визначається П(С)БО 11 «Зобов’язання» [10], а в міжнародній практиці - МСБО 37 «Забезпечення, умовні зобов'язання та умовні активи», МСБО 1 «Подання фінансових звітів», МСБО 10 «Події після звітного періоду», МСБО 12 «Податки на прибуток», МСБО 17 «Оренда», МСБО 19 «Виплати працівникам», МСБО 32 «Фінансові інструменти: подання» [11]. Результати порівняння змісту національних та міжнародних облікових стандартів щодо зобов'язань викладені у табл. 2.

Таблиця 2

Порівняння змісту національних та міжнародних стандартів з обліку зобов'язань

\begin{tabular}{|c|c|c|}
\hline \multirow{2}{*}{$\begin{array}{c}\text { Ознака } \\
\text { порівняння }\end{array}$} & \multicolumn{2}{|c|}{ Результат порівняння } \\
\hline & \begin{tabular}{|c|c|}
$\Pi(\mathrm{C})$ БО 11 & \\
\end{tabular} & МСБО 37 \\
\hline Поняття & \multicolumn{2}{|c|}{$\begin{array}{l}\text { теперішня заборгованість суб’єкта господарювання, яка виникає в результаті минулих } \\
\text { подій і погашення якої, за очікуванням, спричинить вибуття ресурсів із суб’єкта } \\
\text { господарювання, котрі втілюють у собі економічні вигоди }\end{array}$} \\
\hline Визнання & $\begin{array}{l}\text { зобов’язання визнається, якщо його оцінка } \\
\text { може бути достовірно визначена та існує } \\
\text { ймовірність зменшення економічних вигід } \\
\text { у майбутньому внаслідок його погашення. } \\
\text { Якщо на дату балансу раніше визнане } \\
\text { зобов’язання не підлягає погашенню, то } \\
\text { його сума включається до складу доходу } \\
\text { звітного періоду }\end{array}$ & $\begin{array}{l}\text { забезпечення слід визнавати, якщо: } \\
\text { 1) суб'єкт господарювання має } \\
\text { теперішню заборгованість (юридичну чи } \\
\text { конструктивну) внаслідок минулої події; } \\
\text { 2) ймовірно, що вибуття ресурсів, які } \\
\text { втілюють у собі економічні вигоди, буде } \\
\text { необхідним догененя } \\
\text { заборгованості; } \\
\text { 3) можна достовірно оцінити суму } \\
\text { заборгованості }\end{array}$ \\
\hline Оцінка & 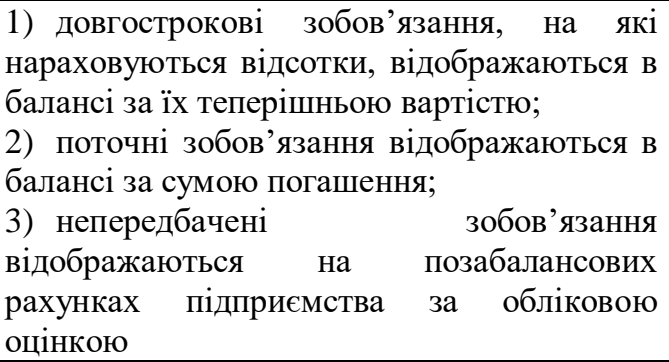 & $\begin{array}{l}\text { сума юридичних або конструктивних } \\
\text { зобов’язань має бути найкращою } \\
\text { оцінкою } \quad \text { видатків, } \quad \text { необхідних } \\
\text { заборгованості на дату балансу }\end{array}$ \\
\hline Види & \multicolumn{2}{|c|}{ довгострокові, короткострокові і непередбачені } \\
\hline
\end{tabular}


Отже, підсумовуючи результати порівняння, варто відмітити, що поняття зобов'язань як у міжнародних, так і у національних стандартах бухгалтерського обліку повністю збігається. Однак між даними стандартами існують відмінності, зокрема, щодо визнання: в національних стандартах розглядається визнання зобов'язань, а в міжнародних - забезпечень. Причому, згідно із МСБО 37 відображення даних забезпечень в балансі відбувається з поділом на довгострокові та короткострокові, тоді як в Україні забезпечення за часом їх залучення взагалі не розділяють.

Оцінка зобов'язань за П(С)БО та МСБО також не збігається. До того ж, у міжнародних стандартах використовуються поняття, відсутні у національній практиці та відповідних П(С)БО. Останнє стосується виокремлення у міжнародній обліковій практиці юридичного та конструктивного зобов'язання: юридичне зобов'язання виникає внаслідок контракту (його явних чи неявних умов) або законодавства, а конструктивне є наслідком дій суб'єкта господарювання, коли:

- суб'єкт господарювання вказав іншим сторонам, що візьме на себе певну відповідальність згідно 3 порядком, установленим його минулою практикою, опублікованими політиками чи достатньо конкретною поточною заявою;

- як наслідок, суб’єкт господарювання створив обгрунтоване очікування у інших сторін, що він виконає ці зобов'язання [12].

Це цілком корелюється із результатами досліджень [13], в яких доведено, що у цивільному та господарському праві зобов'язання виникає з договору незалежно від дій щодо його виконання, в обліку ж зобов'язання не відображається до початку виконання договору: першої поставки або платежу (передплати). Крім того, облік «прив'язаний» до певних моментів в діяльності суб'єктів господарювання: наприклад, невиконання умов договору призводить до штрафних санкцій, які породжують нові зобов'язання в бухгалтерському обліку. У національній практиці застосування поняття юридичних зобов'язань призведе до необхідності введення додаткового активного рахунку «Укладені договори».

Щодо класифікації зобов'язань згідно П(С)БО та МСБО, виявлені основні групи: довгострокові, короткострокові i непередбачені. Однак у міжнародній практиці довгострокові і короткострокові зобов'язання відносять до фактичних, тобто таких, що виникають 3 договорів, контрактів або на основі законодавства та їх вартість можна точно визначити. Непередбачені зобов'язання відносять до умовних - це неіснуючі, але потенційні зобов'язання, бо залежать від майбутніх подій, які можуть виникнути в результаті минулої події [12].

П(С)БО 11 зазначає, що непередбачене зобов'язання - це:

- зобов'язання, що може виникнути внаслідок минулих подій та існування якого буде підтверджено лише тоді, коли відбудеться або не відбудеться одна чи більше невизначених майбутніх подій, над якими підприємство не має повного контролю;

- теперішнє зобов'язання, що виникає внаслідок минулих подій, але не визнається, оскільки малоймовірно, що для врегулювання зобов'язання потрібно буде використати ресурси, які втілюють у собі економічні вигоди, або оскільки суму зобов'язання не можна достовірно визначити.

Інформація про непередбачені зобов'язання повинна розкриватися у примітках до фінансової звітності як стислий опис зобов'язання та його сума; невизначеність щодо суми або строку погашення; сума очікуваного погашення зобов'язання іншою стороною [10].

Однак, існують деякі практичні проблеми застосування даного стандарту, зокрема, що стосується оцінки непередбачених зобов'язань: 3 одного боку, їх сума 
(вартість) визначається за обліковою оцінкою, а з іншого, - іï не можна достовірно визначити. Крім того, щоб оцінити суму або строк погашення, підприємству необхідно докласти додаткових зусиль, спрямованих на аналіз джерел виникнення таких зобов'язань та визначення ризиків їх впливу на фінансовий стан підприємства. Така ж сама ситуація спостерігається і щодо оцінки забезпечень - зобов'язань 3 невизначеними сумою або часом погашення на дату балансу: забезпечення використовується для відшкодування лише тих витрат, для покриття яких вони були створені, а їх оцінка не $\epsilon$ достовірною та може бути визначена лише на основі попередніх розрахунків.

Така неузгодженість нормативно-правових актів в частині оцінки непередбачених зобов'язань та забезпечень негативно впливає на прийняття ефективних управлінських рішень. Для вирішення ідентифікованої проблеми пропонується введення міжнародних стандартів в якості обов'язкових не тільки для суб'єктів господарювання, що мають суспільну значущість, а й для усіх юридичних осіб. Застосування міжнародних регламентів підвищить інвестиційну привабливість підприємства та допоможе зосередженню уваги менеджменту не на узгодженні дефініцій, а на прийнятті ефективних управлінських рішень.

Висновки. За результатами дослідження констатовано, що відсутність єдиного трактування поняття «кредиторська заборгованість», зокрема, у вітчизняних облікових регламентах, $\epsilon$ фактором, що утруднює ефективне управління розрахунками iз постачальниками та підрядниками. Для вирішення цієї проблеми пропонується введення міжнародних стандартів в якості обов'язкових для всіх вітчизняних суб'єктів господарювання.

Напрямом подальших досліджень виступить пошук шляхів вдосконалення процесу управління кредиторською заборгованістю.

\section{СПИСОК ВИКОРИСТАНИХ ДЖЕРЕЛ}

1. Гончарук Р.П. Сутність та класифікація кредиторської заборгованості: колізії наукових підходів. / Р.П. Гончарук // Вісник Житомирського державного технологічного університету. Серія: Економічні науки. - 2015. - №. 1(59), Ч. 1. - С. 4851.

2. Дублей В.В.Необхідність управління дебіторською та кредиторською заборгованостями в сучасних умовах. / В.В. Дублей, М.М. Гуменюк // Журнал Науковий огляд. - 2016. - № 11 (32). - С. 1-9.

3. Чорненька О. Б. Аналіз наукових підходів щодо сутності кредиторської заборгованості та ії класифікації. / О. Б. Чорненька // Вісник економічні науки. - 2017. №20. - С. $207-212$.

4. Хохлов М.П. Управління дебіторською та кредиторською заборгованістю підприємства / М.П Хохлов, О.С Корнієнко// Економіка і суспільство. - 2017. - №10. С.402-407.

5. Майборода О.Є. Характеристика сутності та поняття дебіторської і кредиторської заборгованості. / О.С. Майборода, І.П. Косарєва, І.О.Корабейнікова // Економіка і суспільство. - 2018. - №15. - С. 396-402.

6. Томчук Е.Ф. Аналітичне забезпечення управління кредиторською заборгованістю підприємства. / Е.Ф. Томчук // Науковий вісник Львівського національного університету ветеринарної медицини та біотехнологій імені С.3. Гжицького. - 2016. № 2 (69). - C. 160-164. 
7. Про бухгалтерський облік та фінансову звітність: Закон України № 996-XIV від 16.07.1999 р. за станом на 16.09.2019. [Електронний ресурс] / Режим доступу: http://zakon3.rada.gov.ua/laws/show/996-14.

8. Національне положення (стандарт) бухгалтерського обліку 1 «Загальні вимоги до фінансової звітності»: наказ Міністерства фінансів України № 73 від 07.02.2013 р. за станом на 16.09.2019. [Електронний ресурс] / Режим доступу: http://zakon2.rada.gov.ua/laws/show/z0336-13.

9. Цивільний Кодекс України № 435-IV від 16.01.2003 р. за станом на 16.09.2019. [Електронний ресурс] / Режим доступу: http://zakon4.rada.gov.ua/laws/show/435-15.

10. Положення (стандарт) бухгалтерського обліку 11 «Зобов`язання»: наказ Міністерства фінансів України № 20 від 31.01.2000 р. за станом на 16.09.2019. [Електронний ресурс] / Режим доступу: http://zakon2.rada.gov.ua/laws/show/z0085-00.

11. Міжнародний стандарт бухгалтерського обліку (IASB) 37 «Забезпечення, непередбачені зобов'язання та непередбачені активи». [Електронний ресурс] / Режим доступу: http://zakon2.rada.gov.ua/laws/show/929_051.

12. Хомик П. М. Порівняльний аспект обліку заборгованості підприємства за П(с)БО та МСФ3 (IAS). / П. М. Хомик, М. А. Кулик // Проблеми теорії та методології бухгалтерського обліку, контролю і аналізу. - 2012. - № 3 (24). - С. 503-510.

13. Гевлич Л.Л. Особливості підходів до визначення сутності поняття «поточні зобов'язання» та їх класифікації. / Л.Л. Гевлич, Л.І. Катранжи // Фінанси, облік, банки. - 2017. - №1 (22). - C. 70-78. 